\title{
Dovilè Troskovaitè
}

Vilnius University. Faculty of History

e-mail: dovile.troskovaite@gmail.com

ORCID ID: 0000-0001-7328-1913

\section{he Karaite communities: harnessing the}

\section{multi-lingual linguistic strategies for}

\section{nationalism}

\author{
DOI: http://dx.doi.org/10.12775/FT.2020.004
} (c) $\bigodot_{\text {BY }}$ TD $_{\text {International (CC BY-ND 4.0). }}$ The text is available under a Creative Commons Attribution-NoDerivatives 4.0
Into

Dr. Dovilè Troskovaite is an assistant professor at Vilnius University, Faculty of History. Her field of research focuses mainly (but is not limited to) on the history of East European Karaites, their relations with Rabbinite Jews and the dominating society through though $18^{\text {th }}-20^{\text {th }}$ centuries. She is an author of the dissertation "Formation of Polish and Lithuanian Karaite identity in the $19^{\text {th }}-20^{\text {th }}$ centuries: between separation and adaptation" (2014) and a range of articles, conference presentations on the topic. In the recent years she was a member of several international projects, implementing research on Jewish history, Identity (trans) formations, and heritage of non-Christian communities in Eastern Europe.

eywords: Karaites; Poland; language planning; Seraja Szapszał; Turkic language; Turkey

bstract: The Karaites communities of former Polish - Lithuanian Commonwealth in the beginning of the $20^{\text {th }}$ century started a discussion in their communal press on which language they should adopt as their communal or national language. This view remained important during the first half of $20^{\text {th }}$ century. It was considered as a tool for social and cultural consolidation of the communities and as an important aspect of their social image in the eyes of Polish society. Karaite leaders tried several different strategies for establishment of national language, starting from traditional bilingualism (Hebrew - Turkic) to different combinations of Russian - Hebrew, Polish - Turkic and etc. These initiatives grew stronger after the World War 1, when ethnic nationalism was arising both in Karaite communities and in dominating Polish society. The analysis of these language strategies was done using a model language planning elaborated by Geoffrey Haig in Kurdish language in modern Turkey, under the politics of Kemal Ataturk (Mustafa Kemal Atatürk, 1881-1938). The article has highlighted these strategies, analyzed argumentation, and presented linguistic reforms implemented in the Karaite communities in the first half of the $20^{\text {th }}$ century. It was argued that the social image of Karaites in the dominating society played an important role in decision making by Karaite leaders. It was also understood that language was not only an important aspect of Karaite cultural identity but also a tool for integration into dominating society. 


\section{Introduction ${ }^{1}$}

Language is undoubtedly one of the most important cultural markers of any cultural, ethnic or national group, which importance grows stronger in the modern times. It is still one of the most significant aspects to define one's identity. It is also of a crucial importance in constructing, developing and maintaining collective identity of a certain group. Non-dominating groups living in different cultural surrounding are of particular interest in this respect. They not only implement language planning strategies within the communities to maintain their distinct identities, but have to deal with the language(s) of dominating society. On the one hand, dominating language can be an obstacle for minority's ability to maintain their own language. But on the other hand, knowledge of language of the dominating group can be perceived an important factor of minority's integration. This article focused on language planning strategies, discussed and implemented in Karaite communities in the first half of the $20^{\text {th }}$ century. Analysis was done using a model of language planning elaborated by Geoffrey Haig, in Kurdish language in modern Turkey, under the politics of Kemal Ataturk (Mustafa Kemal Atatürk, 1881-1938). Geoffrey Haig had observed ${ }^{2}$ that there are two levels of language planning - textual, related to the forms of language (script, grammar, lexicon) and functional, which reveals itself through prescribing certain role, image or status for particular language or dialect. The author also coined a term invisibilisation, which can be defined as the deliberate removal or concealment of obvious signs of the existence of a particular culture in order to make this culture invisible. Having illustrated three aspects of invisibilisation which are physical, virtual, and devaluation, the functional relocation of Turkish, Kurdish and Arabic languages became one of the key elements of language reforms in Ataturk's Turkey, which strongly affected the language planning process among Polish Karaites ${ }^{3}$.

The strategies for language planning are distinctive to minority communities because of the need to adapt to the environment of the dominating culture(s). As we will see later, the example of Polish Karaite community suggests that the smaller the community is, the more intensive language planning strategy it implements. The fact that Polish Karaites were geographically mobile was shown in the ethnic group's migration between different linguistic environments - Polish, Ukrainian, Russian, Tatar (Turkic) and Lithuanian. This made them to easily integrate in these places economically, speaking in the different languages on daily basis. Besides, $20^{\text {th }}$ century Polish Karaite communities maintained historical traces and family relations in neighboring countries, becoming a fusion of Eastern European Karaites. On the basis of these two aspects different possible strategies of language planning are suggested.

\footnotetext{
The article is a part of the project Development of non-Christian identity in Lithuania in $19^{\text {th }}-20^{\text {th }}$ centuries, funded by the Lithuanian Research Council under the state program Dissemination of Lithuanistic research 2016-2024 (Valstybinè lituanistinių tyrimų sklaidos 2016-2024 m. programa), contract No. S-LIP-18-33.

2 G. Haig, The Invisibilisation of Kurdish: the other side of language planning in Turkey, [in:] Die Kurden: Studien zu ihrer Sprache, Geschichte und Kultur, ed. S. Conermann, G. Haig, Schenefeld, 2004, p. 121.

3 Ibidem.
} 
Eastern European Karaites have some important features that make the analysis of their linguistic politics of particular interest. This innumerous communities, professing non-Rabbinic Judaism shifted to the Grand Duchy of Lithuania and Poland about the beginning of the $15^{\text {th }}$ century which despite intensive religious and administrative relationship with $\mathrm{Jews}^{4}$ on one hand and integration into Christian society ${ }^{5}$ on the other hand, remained unassimilated. Living in small communities, earning from leasing, crafts and small trade, they shifted from one settlement to another while adopting the dominating vernacular, as one of those, used on daily basis. But then, they also managed to maintain sense of belonging to their original certain community. Such varieties of linguistic practices in a numerically small community suggests important scholarly insights about language politics and its planning.

Until the beginning of the $20^{\text {th }}$ century, most of the community members were adherent to traditional bilingualism of Hebrew and Turkic, but then various combinations of Russian - Hebrew, Polish - Turkic appeared. It is noteworthy to mention that World War 1 changed the geopolitical situation in the Eastern Europe and brought Karaites to another stage of language planning. This phenomenon as a combination of several different processes was inspired and shaped first of all by modernization within Jewish environment. Inside Jewish tradition, Karaites experienced a growing impact of modernization, which had offered a possibility of combining traditional religiosity with the need to acculturate - a sort of compromise between assimilation and segregation. Later, the overwhelming impact of ethnic nationalisms in Eastern Europe brought an attempt of different ethnic groups to describe themselves by setting boundaries from other groups. This led to the emergence of Karaite national feelings, which brought a growing need to separate themselves from Rabbinic Jews. In the cultural sphere the process of nationalization revealed itself in search for national history, language, costume, cuisine, etc. Karaite community faced pressure from dominating society, which was offering a model of national ethnic self-identity on one hand, which after the establishment of national states, asked for a certain level of loyalty to it on the other. All these processes called for language reforms and shaped their planning strategies, implemented by Karaite elites in the $20^{\text {th }}$ century. The article will deal with these strategies by analyzing the emergence of different language politics, the role of particular languages in the community in different historical periods, and the implementation of reforms to establish the national language of Polish Karaites.

\footnotetext{
4 Until 1765 Karaite communities in the Grand Duchy of Lithuania were administered by the Jewish Vaad institution. The aim of this administration was to collect state-imposed poll tax from all communities that professed Judaism, and Karaites felt upon Vaad's jurisdiction. More on this topic: A. Michałowska-Mycielska, Sejm Żydów Litewskich (1623-1764), Warszawa, 2014.

5 Already in the second half of the $19^{\text {th }}$ century Karaites in Russian Empire gained the same legal rights as local Orthodox believers, which meant recognition of uniqueness of Karaite faith and ethnicity by Imperial government. For more: D. Troskovaité, „Lenkijos ir Lietuvos karaimu savivokos formavimas XIX a. vid. - XX a. pirmoje pusèje: tarp atsiskyrimo ir prisitaikymo“, (PhD thesis, defended at Klaipedda university, Klaipèda, Lithuania, 2014, supervisor dr. Darius Staliūnas), p. 33-45.
} 


\section{Between Turkic and Russian: the first attempts in search of a national language}

folia toru niensia

The fact is that most Karaites were capable of using more than one language in their everyday life. However, in different historical periods, ideologically, the most important languages were two - Hebrew language which was used for religious purposes and literary works until the end of $19^{\text {th }}$ century, and Turkic vernacular which was spoken by Eastern European Karaites. ${ }^{6}$ Before becoming a national Karaite language on the 1930s, the non-prestigious status was assigned to it, which encouraged attempts to reform it. But Karaites were not the only community in Eastern Europe that managed to implement the reform of Turkic vernacular. The first reforms of Turkic dialects appeared in Russian Empire in the $19^{\text {th }}$ century and were initiated by Nikolaj Ilminski (1822-1891) ${ }^{7}$. He was a founder of so called "IIminski system", which accommodated language reform, education and region in spreading Orthodox faith in Russian Empire. By adopting Cyrillic script to Kazakh vernacular, N. Ilminski sought to increase the gap between this language and its speakers Kazakhs on the one hand and the Tatars and the influence of Islam to Khazak culture, on the other ${ }^{8}$. At the same time, it had to foster the acculturation of the Khazaks and deepen their involvement into Russian civilization by replacing of Arabic alphabet, usually used for Turkic dialects in the Central Asia and the Far East, with Cyrillic ${ }^{9}$. Other important aspects of the Ilminski's system were also related to the use of language - Orthodox liturgical texts started to be translated into Turkic vernaculars, Kazakhs have been trained to serve as Orthodox clergy and local teachers ${ }^{10}$. N. Ilminski's project attracted a number of followers who continued the activities after his death. The importance of Ilminski's initiative cannot be overestimated. It shaped the attitude and policy of the Russian Empire towards its Muslim inhabitants and suggested ways of treating other minority languages in the Empire ${ }^{11}$. In general, alphabet reforms featuring the replacement of one writing system by another was a fairly widespread practice in the Russian Empire for example after the 1864 uprising Cyrillic was introduced in Lithuania for writing in Lithuanian. It continued to be obligatory writing system until $1904 .{ }^{12}$ However, all these initiatives originated outside the communities for which they were intended and adapted. This circumstance had important implications for their spread and establishment.

6 There were two dialects of it - Troki/Trakai - Luck and Crimean one. Due to the geographical distance of these communities and other reasons both dialects were developing independently.

He was a founder of the Brotherhood of Saint Guria (rus. Братство Святого Гурия), established in October 1867. The brotherhood aimed to work in Kazan diocese in spreading Orthodox faith among Muslims in Volga region and Siberia and in preventing already baptized local inhabitants from returning to Islam, which sometimes was a large-scale phenomenon. The N. Ilminski missionary activities were based on the use of local languages and local teachers to promote Orthodoxy and conversion to it among people who did not understand Russian language. For more: R. P. Geraci, Window to the East. National and Imperial Identities in Late Tsarist Russia, Ithaca and London, 2009, pp. 47-85.

8 D. Staliūnas, Rusinimas: Lietuva ir Baltarusija po 1863 metu, Vilnius, 2009, p. 386.

9 M. Ö. Tuna, Gaspirali V. Il'minskii: Two Identity Projects For The Muslims Of The Russian Empire, Nationalities Papers, vol. 30: 2002, No. 2, p. 270.

10 M. Ö. Tuna, op. cit., p. 268.

11 Ibidem, p. 255.

12 M. Dolbilov, Imperijos biurokratija ir lietuvių kalbos lotyniškais rašmenimis draudimas 1864-1882 m., [in:] Radžiu draudimo metai, ed. D. Staliūnas, Vilnius 2004, p. 111-138. 
In the face of these reforms, Karaite community was rather an exception. First of all, contrary to the above-mentioned ethnic groups, the community voluntarily adopted Cyrillic alphabet for their spoken Turkic vernacular. This was followed by gradual shift to Russian language, which began after annexation of territories of the Grand Duchy of Lithuania, Poland and Crimea by Russian Empire in the end of the $18^{\text {th }}$ century ${ }^{13}$. The peak of this acculturation movement among certain Karaites was the discussion on the use of Russian as native Karaite language in the late Tsarist Russia. It was launched in the pages of liberal communal newspaper Karaite life (rus. Караимская жизнь), published under editorship of V. Sinani in Moscow in 1911-1912 ${ }^{14}$. Language planning was a part of broader question of Karaite national identity and community's role among European nations. The journal urged for establishment of Karaite national language. The idea of own language was characteristic to ethnic nationalisms in the region, and Karaites were not exception of this trend. On the other hand, the community had to search for native language because geographically distant Karaite settlements were dominated by different linguistic configurations of Hebrew, Turkic, Russian and, to smaller extent, other local languages and dialects dominating in their local dwelling places. The most eloquent in this context is the article by David Kokizov ${ }^{15}$, where the author encouraged Karaites to adopt Russian as "a civilized" language to their everyday life, education, and religious services, and abandon Tatar (that is, Turkic) which was said to be poor, uncivilized, and used by small number of people. It is important to note that according to D. Kokizov, the Hebrew language, though native for Russian Karaites, was already lost and he did not suggest any strategy to re-establish it in the community ${ }^{16}$. Such discussion was an echo of the growing ethic nationalism among minority groups in the Empire - Lithuanians, Poles, Byelorussians and other ethnic groups which experienced the rise of national feelings and separateness from Russian environment ${ }^{17}$.

These ideas of language planning were welcomed in the liberal circles of Russian Karaites. However, it is hard to estimate their impact to the general Karaite population. On the one hand, we can state firmly, that Russian was broadly used by Karaites, because two most important Karaite journals Karaite life and its follower Karaite word (rus. Караимское слово) ${ }^{18}$ were published in Russian, besides, it was a lingua franca of Imperial Karaites in different communities, and the knowledge of Russian as well as other local languages was a feature, attributed to Russian Karaites

${ }_{13}$ D. Shapira, The Turkic languages and Literatures of East European Karaites, [in:] Karaite Judaism. A Guide to its History and Literary Sources (Handbook of Oriental Studies. Section 1: The Near and Middle East, vol. 73), ed. M. Polliack, 2003, pp. 657-658.

${ }^{14}$ During two years of publishing, twelve issues of journal Karaite Life were released. Though published by communal leaders in Moscow, the journal was addressed mainly to Crimean communities, with the lesser contribution by the North Western Karaites. The fact that the first communal journal was published in Russian indicates that the initiators of it were affected by acculturation and accepted the language of the dominating society and were eager to integrate into surrounding environment.

15 D. Kokizov, Ruskij ili tatarskij, Karaimskaia Zhizn', vol. 2: 1911, p. 35.

16 D. Kokizov, op. cit., p. 35.

17 On the nationalism of small nations, plese refer to Miroslav Hroch, Mažosios Europos tautos, Vilnius 2012.

18 The journal was published in Vilnius in 1913-1914 by local Karaites as community's monthly on history and literature. During two years of publishing twelve issues of this journal were released (six in 1913 and three double issues in 1914). Three survived volumes of Karaite word are stored at S. Shapshal Karaim Ethnographic Museum in Trakai (Lithuania) but I was unable to identify locations of other issues. 
by non-Karaites ${ }^{19}$. But on the other, besides afore mentioned text by D. Kokizov, no other texts refer to Russian as a possible national Karaite language. Despite the fact, that it was broadly used by Karaites, one source is not enough to make more reliable conclusions about the place of Russian language in the ideology of toru Karaite national project.

\section{Turkic language: from uncivilized vernacular to national language}

However, the end of the WW 1 was a turning point in Karaite language planning strategies. The pressure of nationalization was two-sided: the dominating Polish society re-established the statehood and the atmosphere was raising optimistic notions among minority groups, who were at the pressure under Tsarist rule $^{20}$; while inside Karaite community the nationalization strengthened the feeling of separate Karaite ethnicity and increased alienation with the Rabbinite Jews. The emerging Polish state was seen by Karaite leaders as an opportunity to establish community as a separate entity. Due to the impact of surrounding newly established states, Karaite elite adopted the model of ethno-linguistic nationalism. It means that neither Russian society, nor Jewish community maintained an important intellectual, cultural and social power in Karaite language planning, but Polish society and Poland as a state. This is an important shift from Russian language and orthography to Polish language and Latin alphabet, but it is also a revival of Turkic language, which was assessed negatively by Karaite elite but was widely spoken by most community members.

To analyze the development of Karaite language policy, the study of G. Haig ${ }^{21}$ is highly important. Using his concept of invisibilisation, the language planning strategies in Karaite community can be analyzed in three important aspects: 1) First is the role and place of Turkic language, 2) second, is the adoption of orthography for Karaite vernacular, and 3 ) third, is the role of Hebrew in the community's language strategy before the WWII.

As it was said, in the beginning of the $20^{\text {th }}$ century Karaite elite perceived Russian language as culturally and intellectually developed, and encouraged to adopt it as national Karaite language ${ }^{22}$. The Turkic vernacular, spoken by most community members in everyday life, was assessed negatively as barbaric and uncivilized, inappropriate for intellectual activities of Karaite national revival. In 1919, after incorporation of Vilnius region to Polish state, Karaites became the subjects of this country. It was soon understood that attachment to anything related to former Empire was irrelevant and this perception affected language planning strategies in the community. Instead of integrative nature of this strategy, which would mani-

\footnotetext{
19 M. Kizilov, The Sons of Scripture. The Karaites in Poland and Lithuania in the Twentieth Century, Berlin 2015, p. 81.

20 Polish Karaites warmly welcomed the change of power after 1919, when Vilnius region, inhabited by Karaite communities in the towns of Vilnius and Trakai, were attached to Poland. The public greetings were expressed, Polish language was adopted in communal use, the loyalty to Poland was demonstrated on every occasion.

21 G. Haig, The Invisibilisation of Kurdish: the other side of language planning in Turkey, [in:] Die Kurden: Studien zu ihrer Sprache, Geschichte und Kultur, ed. S. Conermann, G. Haig, Schenefeld, 2004, p. 121.

22 D. Kokizov, Ruskij ili tatarskij, Karaimskaia Zhizn', vol. 2: 1911, p. 35.
} 
fest to the adherence to the language of dominating society, community's leaders were speaking for separate Karaite ethnicity. This was a turning point to a lesser integration and acculturation to the dominating society and opened the floor to the status planning of Turkic vernacular in the community.

The initiative of language planning belonged to the chief Karaite leader Seraja

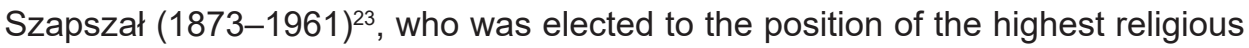
authority - hacham in 1927 and began his duties a year later. Before arriving to Poland, he was living in Turkey and belonged to the circle of modern intellectuals, following the agenda of Kemal Ataturk, who initiated a Turkish language reform by adopting Latin script, erasing traces of Arabic language and standardizing it. It seems that Szapszał followed these ideas and applied them for status planning of Turkic vernacular in Karaite community. It was for the first time when Turkic vernacular was standardized using already reformed Turkish language as an example: the Latin alphabet was adopted with Polish (in Poland), and Lithuanian (in Lithuania) diacritical signs, Hebrew words were replaced by Turkish ones, and the dialect was entitled Karaite language. The latter marked a turning point in the birth of Karaite national language - community started to associate themselves with this language, literary works, mainly poetry, was created and the national press was printed in Turkic. The first and the most important periodical in Turkic dialect was "Karaj Awazy" (Karaite voice), printed in Luck under editorship of Aleksandr Mardkowicz (1895-1944) from 1931 until 1838². It was the 1930s, when Karaite national press in Turkic dialect flourished - in Panevéžys (Lithuania) a journal "Onarmach" (Progess) appeared, while the Troki Karaites published "Dostu Karajnyn" (Karaite friend). Though the latter were short lived, their existence contributed in entrenching the status of Karaite language in the ideology of Karaite nationalism and strengthening Karaite adherence to it.

The orthography of Karaite national language deserves separate attention. As Pierre Giorgio had stated, there is no necessary relation between the language and the way it is written down. One can adopt any orthographic system to a certain language. In the course of time, Karaites used Hebrew and Cyrillic scripts for Turkic vernacular. The decision to use Latin alphabet, taken in the $20^{\text {th }}$ century, lied on such arguments as acculturation, secularization and dissociation from Jewishness ${ }^{25}$.

Another stage of language planning strategy in Polish Karaite community was invisibilisation of Hebrew, which was broadly used by Karaites in religious life, intellectual activities, correspondence with other Karaite as well as Jewish communities, and etc. until the end of the $19^{\text {th }}$ century. Though due to secularization and growing alienation with Jews, Karaite knowledge of Hebrew was decreasing, certain words indicating religious holidays, months, names of religious objects and rituals shifted to the Turkic vernacular, spoken by Karaites. It was these words,

\footnotetext{
${ }^{23}$ For more about S. Szapszal activities: D. Shapira, A Jewish Pan-Turkist: Seraya Szapszał (Şapşaloğlu) and his work „Quirim Qaray Türklëri“ (1928) (Judeo-Turkica XIII), Acta Orientalia Hungaricae, No. 58: 2005, pp. 349-380.

24 A.Sulimowicz, Karaimskie czasopisma, Awazymyz: pismo historyczno-spoleczno-kulturalne Karamów, Nr. 2-3, 1999, p. 13-14.

25 P. G. Borbone, Choice of Script as a Mark of Cultural or/and National Identity [online], p. 14 [access 21 X 2019]. Available on the World Wide Web: http://www.academia.edu/539603/Choice_of_Script_as_a_Mark_of_Cultural_ or_and_National_Identity.
} 
which were changed or replaces in order to erase the signs of Hebrew language in it. The most vivid example is the modification of the title hacham (hebr. wise, skillful man) to hachan ${ }^{26}$, by the already mentioned S. Szapszał in order to sound more Turkic (Turkic title khan means «leader, ruler»). After introduction of this modified term to the Ministry of Religious Affairs and Public education in 1927, it was included into official use in legal documents, Karaite community's regulations and etc. ${ }^{27}$ The similar invisibilisation policy was implemented in Turkey with the Kurdish aiming to diminish its status and visibility in the society ${ }^{28}$. This reformed term also expressed Turkic ethnicity - the core element of modern Karaite identity and demonstrated a clear relation with pan-Turkism that prevailed mostly among Islamic groups of Turkic origin, like among local Polish Tatars, who were unsuccessful to adopt pan-Islamic ideas in beginning of the $20^{\text {th }}$ century.

Another example illustrates invisibilisation of Hebrew on the one hand, and building up a prestigious status of Turkic which, according to Haig's concept, can be addressed as functional language planning, on the other. In October 1937 S. Szapszał presented a list of Karaite holidays to the Ministry of Religious Affairs and Public Education ${ }^{29}$, where he indicated the titles and dates of Karaite holidays and explained their meaning by giving quotes from Torah, which is referred as the Old Testament in the source. (Table 1).

Table 1. List of holidays celebrated by Karaite community in 1937 as presented by S. Szapszał (Source: Ministry of Religious Affairs and Public Education, CAMR, sig. 1464) $)^{30}$

\begin{tabular}{|c|l|l|l|l|}
\hline No. & \multicolumn{1}{|c|}{ Holiday } & $\begin{array}{c}\text { Quotes from Old } \\
\text { Testament }\end{array}$ & \multicolumn{1}{|c|}{ Dates } & Remarks \\
\hline 1 & Jilbasz $^{31}$ (New year) & Exodus XII, 2 & 1 artarych (2 April) & \\
\hline 2 & $\begin{array}{l}\text { Pascha (Easter }{ }^{32} \text { ) } \\
\text { Pascha (the last } \\
\text { day of Easter) }\end{array}$ & Lewit. XXIII, 5 & 15 April (16 April) & \\
\hline 3 & Zielone Święto & Lewit. XXIII, 16 & $\begin{array}{l}\text { 6 baszkuszachan } \\
\text { (5 June) }\end{array}$ & \\
\hline
\end{tabular}

26 For example, The Central Archives of Modern Records (pol. Archiwum Akt Nowych w Warszawie, hereinafter CAMR), sig. 1462, Project of Legislation of Karaite community status in Poland, pp. 10-15 and other.

27 CAMR, sig. 1462, Legislation of Karaite community status in Poland, 1933, Wilno/Vilnius, pp. $297-313$.

28 G. Haig, The Invisibilisation of Kurdish: the other side of language planning in Turkey, [in:] Die Kurden: Studien zu ihrer Sprache, Geschichte und Kultur, ed. S. Conermann, G. Haig, Schenefeld, 2004, p. 121-150.

29 CAMR, sig. 1464, S. Szapszał to the Ministry of Religious Affairs and Public Education, 1937, Wilno/Vilnius, pp. 6465.

30 The table is given in an original form, as provided in the source, except of remarks, which are added from another source, also composed by S. Szapszał for unknown reasons and without indicated recipient (CAMR, sig. 1646, pp. 70-71). All explanations, given in the table in brackets, were originally presented in Polish, however, here are translated into English. All terms are left as given in the source even though they are misleading (for example, Old Testament instead of Torah).

31 Please note that all holidays are spelled according to the Polish language rules, where sz is used for sh, and written with Polish diacritical signs, like ł for Boszatłych kiuniu (bellow in the table).

32 S. Szapszał intencially used a stereotypical and missleading juxtaposition of Jewish Passover and Christian Easter. 
Table 1 (continued)

\begin{tabular}{|c|c|c|c|c|}
\hline 4 & Kuban (fasting) & $\begin{array}{l}\text { moral, } \\
\text { customary }\end{array}$ & 9 ułahaj (5 August) & $\begin{array}{l}\text { Fasting in } \\
\text { commemoration } \\
\text { of demolition } \\
\text { of Jerusalem } \\
\text { Temple }\end{array}$ \\
\hline 5 & Terua & Lewit. XXIII, 24 & $\begin{array}{l}1 \text { ajrychsyaj } \\
\text { (25 September) }\end{array}$ & \\
\hline 6 & Boszatłych kiuniu & $\begin{array}{l}\text { Lewit. XXIII, } 27 \text {, } \\
\text { XVI, } 29-31\end{array}$ & $\begin{array}{l}10 \text { ajrychsyaj } \\
\text { (4 October) }\end{array}$ & \\
\hline 7 & $\begin{array}{l}\text { Alaczych } \\
\text { (the first day) } \\
\text { Alaczych } \\
\text { (the last day) }\end{array}$ & Lewit. XXIII, 34 & $\begin{array}{l}15 \text { ajrychsyaj } \\
\text { (9 October) } \\
21 \text { ajrychsyaj } \\
\text { (15 October) }\end{array}$ & \\
\hline 8 & Bienczy Torayn & $\begin{array}{l}\text { moral, } \\
\text { customary }\end{array}$ & $\begin{array}{l}28 \text { ajrychsyaj } \\
\text { (22 October) }\end{array}$ & $\begin{array}{l}\text { Holiday at the } \\
\text { beginning of the } \\
\text { readings of the } \\
\text { Holy Scripture } \\
\text { (pol. Pismo } \\
\text { Święte). }{ }^{33}\end{array}$ \\
\hline
\end{tabular}

The document reveals not only invisibilisation of Hebrew language in the community but also the religious traditions associated with it - the names of religious holidays were presented by giving misleading association with Christian festivals. For example, the holiday, indicated by S. Szapszał as Zielone Święto looks like misspelled title of Pentecost (Pol. Zielone Świątki) - traditional Christian feast of the Descent of the Holy Spirit, whose genesis is associated with pre-Christian - pagan - fertile spring rites. However, originally this is Shavuot - Jewish holiday of Torah giving on the mount Sinai. Though both have symbolic relation with nature, planting and agriculture, but the meaning of both is completely different. The same can be said about misleading collation of Jewish Passover with Christian Easter (line 2, Table 1) or Torah and the Old Testament (column 2, Table 1), given by S. Szapszał in the document under discussion. No doubt, this was done intentionally as one of the steps of language planning strategies in Karaite community and a part of the Karaite national project.

The devisualisation of Hebrew content in Karaite religious holidays, presented in the S. Szapszał's list can be seen even more clearly if compared with Jewish (Rabbinite) holidays:

${ }_{33}$ In the Turkisized form of the holiday the term Torah was preserved, however, in the column Remarks S. Szapszal used the term The Holy Scripture. 
Table 2. The comparison of Karaite and Jewish holidays

folia

\begin{tabular}{|c|c|c|c|}
\hline No. & Holiday (Rabbinic tradition) & Dates (Rabbinite/ Karaite) & $\begin{array}{c}\text { Holiday } \\
\text { (Karaite tradition) }\end{array}$ \\
\hline 1 & Rosh HaShana (the first day) & 1 Tishrei/ 1 Airuqhs ai & Terua \\
\hline 2 & Jom Kipur & 10 Tishrei/ 10 Airuqhs ai & Boszatłych kiuniu \\
\hline 3 & $\begin{array}{l}\text { Sukot ( the first day) } \\
\text { Sukot (the last day) }\end{array}$ & $\begin{array}{l}15 \text { Tishrei/ } 15 \text { Airuqhs ai } \\
21 \text { Tishrei/ } 21 \text { Airuqhs ai }\end{array}$ & Alaczych \\
\hline 4 & Simchat Tora & 22 Tishrei/ $28^{34}$ Airuqhs ai & Bienczy Torayn \\
\hline 5 & $\begin{array}{l}\text { Hanukkah (the first day) } \\
\text { Hanukkah (the last day) }\end{array}$ & $\begin{array}{l}25 \text { Kislev } \\
29 \text { Kislev }\end{array}$ & -35 \\
\hline 6 & $\begin{array}{l}\text { Purim (the first day) } \\
\text { Purim (the last day) }\end{array}$ & $\begin{array}{l}14 \text { Adar } \\
15 \text { Adar }\end{array}$ & - \\
\hline 7 & $\begin{array}{l}\text { Pesach (the first day } \\
\text { Pesach (the last day) }\end{array}$ & $\begin{array}{l}15 \text { Nisan/ } 15 \text { Artarykh ai } \\
21 \text { Nisan/ } 21 \text { Artarykh ai }\end{array}$ & Pascha \\
\hline 8 & Shavuot & 6 Sivan/ 6 Basz kuskan & Zielone Święto \\
\hline
\end{tabular}

It was shown in the Table 2 that the majority of Karaite holidays are the same as celebrated in Rabbinite community but due to the instalment of Turkic titles instead of Hebrew ones in the $3^{\text {rd }}$ decade of the $20^{\text {th }}$ century, this similarity became invisible for the outsiders, while the nature of holidays inside community remained unchanged.

The different practice of language politics illustrates the sequence of Karaite holidays, published in the journal Karaite word (rus. Караимское слово) in 1914 (Table 3). All titles of religious holidays are given in Hebrew, likewise in Rabbinite tradition (Table 2, column 1). And the remnants of the use of Hebrew calendar were also preserved - the dates of fasting are given according it, while the dates of other holidays were originally indicated in Russian ${ }^{36}$.

\footnotetext{
34 There might be corrections in setting dates of certain holidays because of a) slight differencies in Karaite and Rabbinite calendars; b) due to the leap year - there are 12 months, having 29 or 30 days in Jewish calendar year. There is a 19-year cycle, where the years $3,6,8,11,14,17,19$ are the leap year, with additional adar (Süinuc ai, Sujunc ai, Süvünc ai in Karaite tradition) month.

35 Differently from Rabbinite Jews, Karaites do not recognize Hanukkah as holiday, because, according to Karaite's point of view, the Rabbis did not have the authority to establish a holiday.

36 The list of Holidays for the year 5674, Karaimskoe Slovo, No. 7-8: 1914, p. 18.
} 
Table 3. The calendar of Karaite holidays and fasting until the end of the year 5674 [1914]. (Source: The list of Holidays for the year 5674, Karaimskoe Slovo, No. 7-8: 1914, p. 18.)

\begin{tabular}{|c|c|}
\hline Holiday (as given in the source) & Dates (as given in the source) \\
\hline Purim & Wednesday and Thursday, 26-27 $27^{\text {th }}$ February, 1914 \\
\hline Pesach & Saturday, 29th March, 1914 \\
\hline Shevij-Aceret ( $7^{\text {th }}$ day of Pesah) & Friday, $4^{\text {th }}$ April, 1914 \\
\hline Shavuot & Sunday, $18^{\text {th }}$ May, 1914 \\
\hline Fasting & $9^{\text {th }}$ Tamuz, $20^{\text {th }}$ June, 1914 \\
\hline Fasting & $7^{\text {th }}$ Av, $17^{\text {th }}$ July, 1914 \\
\hline Fasting & $10^{\text {th }}$ Av, 20 $20^{\text {th }}$ July, 1914 \\
\hline Rosh - Hashana (year 5675) & Monday, $8^{\text {th }}$ September, 1914 \\
\hline
\end{tabular}

The Table above shows that before the language planning reform, implemented by S. Szapszał in the $2^{\text {nd }}-3^{\text {rd }}$ decade of the $20^{\text {th }}$ century, Karaites were used to Hebrew titles of religious festivals and names of the months. One more difference is visible when S. Szapszał's document is compared with the list of holidays, published in Karaite word (rus. Караимское слово) - the Purim holiday, celebrated in Karaite community in the beginning of the $20^{\text {th }}$ century, which commemorates the saving of the Jewish people from Haman, an Achaemenid Persian Empire official who was planning to kill all the Jews, was not mentioned by S. Szapszał. Though the motives of such ignorance was not indicated in any documents of my knowledge, the fact itself also reflects the invisibilisation of Jewish tradition among Polish Karaites.

However, the most significant change in the Turkic language was textual changes, analogous to that of the Turkish language. This is a transition from the "sacred" that is Hebrew in the case of Karaites to "secular" that is Latin alphabet. With the refusal of the Hebrew alphabet, the Turkic language was completely secularized, separated from confession and completely disconnected from Jewishness. As in the case of the Turkish language, alongside textual changes of Turkic language, the functional reforms were implemented. The Hebrew language was tried to be removed from public life. In 1923 the representative of the Polish government in the Vilnius region indicated that the Turkic language, which he called the Tatar, "is still used in services by Karaites" 37 , with no mention of Hebrew. In June 1927 The Vilnius Karaite community sent a letter to Vilnius voivoda, stating that "there is a lack of textbooks in Polish for teaching Karaite liturgy and language, which at the same time is also a language of praying and services" 38 . Both quoted documents are probably the first official declaration of Karaite monolingualism. As early as in January 1920 a similar letter was sent by Halicz Karaites to the Ministry of Religious Affairs and Public Education, stating that the community assembly had decided to apply to the ministry for permission and support employ teachers of Karaite and

\footnotetext{
${ }_{37}$ CAMR, sig. 1461, Writing of the governmental representative in Wilno/Vilnius region, 1923, Wilno/Vilnius, p. 18.

38 CAMR, sig. 1465, Karaite community to Wilno/Vilnius Voivode, 1927 m. Wilno/Vilnius, pp. 83-95.
} 
Hebrew languages ${ }^{39}$. It must be noted also, that the naming of the language in Karaite sources, especially those, addressed to the Polish officials - already from 1927 the Turkic vernacular was called Karaite language, making it look like the national language of mono-lingual ethnic group, which fits the framework of ethno-linguistic nationalism that prevailed in the region.

The Turkic vernacular, which became known as Karaite language, was not the only Turkic language, which adopted Latin alphabet in the $20^{\text {th }}$ century. The scarce literary heritage of Lithuanian Karaites indicates, that community, whose members were dwelling in Panevėžys and its neighborhoods, did adopt Latin alphabet with Lithuanian diacritical signs for Turkic vernacular - it was used in the communal journal Progress (Turkic Onarmach) ${ }^{40}$. In the $2^{\text {nd }}$ decade of $20^{\text {th }}$ century such practice was broadly used in the territories of Soviet Union and Central Asia ${ }^{41}$ - for example, in 1925 Latin alphabet was adopted to Azerbaijanian language. Not to speak about Turkey - in 1928 after the nationalist language reform, implemented by Mustafa Kemal Ataturk, the Latin script was installed for Turkic language. This wave of Latinization can be estimated as an effort to gain more prestige for the native languages, and as a mean for Europeanization of particular nations and ethnic groups, which was closely related to the modernization projects within these groups.

\section{Conclusion}

Polish Karaite community experienced an intensive language planning through the first half of the $20^{\text {th }}$ century. While implementing the reform of the Turkic language, the Latin alphabet was used to write it. The final and complete abandonment of the Hebrew alphabet coincided with secularization and construction of a secular national Karaite self-identity, based on the Turkic language. The Hebrew alphabet, which was previously used for writing in Turkic by Karaites, did not meet the ideological requirements for the newly created Karaite identity. On the other hand, the adaptation of the Latin alphabet with the Polish diacritical signs to the Karaite Turkic vernacular essentially meant that the community sought to integrate into the culture of the dominating society. Moreover, the prestige of the Latin alphabet in Polish culture was much greater than that of the foreign and incomprehensible Hebrew, which was associated with Jewish culture and perceived as one of its most striking features.

\section{References}

Author unknown. 1914. „The list of Holidays for the year 5674." Karaimskoe Slovo 7-8:18.

\footnotetext{
${ }^{39}$ CAMR, sig. 1465, Karaite community to the Ministry of Religious Affairs and Public Education, 1920, Wilno/Vilnius, pp. 27-33.

40 The journal was published in Panevėžys in 1934-1939, under the editorship of Mykolas Tinfovičius.

41 P. G. Borbone, Choice of Script as a Mark of Cultural or/and National Identity, [http://www.academia.edu/539603/ Choice_of_Script_as_a_Mark_of_Cultural_or_and_National_Identity], p. 20; M. Sebba, Ideology and Alphabets in the former USSR, [in:] Language Problems \& Language Planning, Vol. 30, No. 2, 2006, p. 102.
} 
Borbone, Pier Giorgio. 2011. "Choice of Script as a Mark of Cultural or/ and National Identity." In Myths, Heroes Gender and Identities. A CLIOHWORLD-CLIOHRES ISHA Reader 4, comp. A. Popa, B. Rentea, 177-188. CLIOHWORLD.

Geraci, Robert P. 2009. Window on the East: National and Imperial Identities in Late Tsarist Russia. Ithaca and London: Cornell University Press.

Haig, Geoffrey. 2005. „The Invisibilisation of Kurdish: the other side of language planning in Turkey." In Die Kurden: Studien zu ihrer Sprache, Geschichte und Kultur, ed. S. Conermann, G. Haig, 121-150. Schenefeld: EB-Verlag.

Hroch, Miroslav. 2012. Mažosios Europos tautos. Vilnius: Mintis. https://doi.org/10.1075/lplp.30.2.02seb.

Jagodzińska, Agnieszka. 2008. Pomiędzy. Akulturacja Żydów Warszawy w drugiej połowie XIX wieku. Wrocław: Wydawnictwo Uniwersytetu Wrocławskiego.

Kizilov, Mikhail. 2015. The Sons of Scripture. The Karaites in Poland and Lithuania in the Twentieth Century. Berlin: De Gruyter.

Kokizov, David. 1911. „Ruskij ili tatarskij.“ Karaimskaia Zhizn’ 2:35.

Letter by Karaite community to Wilno/Vilnius Voivode. sig. 1465. The Central Archives of Modern Records, Poland.

Letter by Karaite community to the Ministry of Religious Affairs and Public Education. sig. 1465. The Central Archives of Modern Records, Poland.

Michałowska-Mycielska, Anna. 2014. Sejm Żydów Litewskich (1623-1764). Warszawa: Dialog.

Peltyn, Samuel. 1885. Projekt reformy w judaizmie ze szczególnym uwzględnieniem jego strony etycznej. Warszawa: Publisher not identified, typ. E. Skiwski.

Project of Legislation of Karaite community status in Poland. sig. 1462. Archiwum Akt Nowych w Warszawie, Poland.

Remarks by S. Szapszal for unknown reasons and without indicatedrecipient. sig. 1646. The Central Archives of Modern Records, Poland.

S. Szapszal to the Ministry of Religious Affairs and Public Education. sig. 1464. The Central Archives of Modern Records, Poland.

Sebba, Mark. 2006. "Ideology and Alphabets in the former USSR." Language Problems and Language Planning, vol. 30, no. 2, pp. 99-125.

Shapira, Dan. 2003. "The Turkic languages and Literatures of East European Karaites." In Karaite Judaism. A Guide to its History and Literary Sources (Handbook of Oriental Studies. Section 1: The Near and Middle East, vol. 73), ed. M. Polliack, 657-658, Leiden: Brill.

Shapira, Dan. 2005. "A Jewish Pan-Turkist: Seraya Szapszał (Şapşaloğlu) and his work „Quirim Qaray Türklëri“ (1928) (Judeo-Turkica XIII).“ Acta Orientalia Hungaricae, 58: 349-380.

Staliūnas, Darius. 2009. Rusinimas: Lietuva ir Baltarusija po 1863 metu. Vilnius: Lietuvos istorijos institutas.

Troskovaité, Dovilè. 2014. „Lenkijos ir Lietuvos karaimu savivokos formavimas XIX a. vid. - XX a. pirmoje puseje: tarp atsiskyrimo ir prisitaikymo." $\mathrm{PhD}$ thiss., Klaipedda university. 
Tuna, Mustafa Özgür. 2002. „Gaspirali v. Il'Minskii: Two Identity Projects for the Muslims of the Russian Empire." Nationalities Papers 20(2): 265-289. https:// doi.org/10.1080/00905990220140658.

Writing of the governmental representative in Wilno/Vilnius region. sig. 1461. The Central Archives of Modern Records, Poland.

Received: 18 V 2020

Accepted: 7 IX 2020 


\title{
Dovilë Troskovaitè
}

Vilnius University. Faculty of History

e-mail: dovile.troskovaite@gmail.com

ORCID ID: 0000-0001-7328-1913

Dr Dovilè Troskovaitė jest adiunktem na Wydziale Historycznym Uniwersytetu Wileńskiego. Jej obszar badań koncentruje się głównie (ale nie wyłącznie) na historii wschodnioeuropejskich Karaimów, ich stosunkach z rabinicznym judaizmem oraz na społeczeństwie dominującym na przestrzeni XVIII-XX w. Jest autorką rozprawy Kształtowanie się polskiej i litewskiej tożsamości karaimskiej w XIX-XX wieku: między separacją a adaptacją (2014) oraz szeregu artykułów, wystąpień konferencyjnych na ten temat. W ostatnich latach uczestniczyła w kilku międzynarodowych projektach zajmujących się badaniami nad historią Żydów, formacjami tożsamościowymi i ich przekształceniami oraz dziedzictwem społeczności niechrześcijańskich w Europie Wschodniej.

\section{Wspólnoty karaimskie: wykorzystanie}

\section{wielojęzycznych strategii językowych dla}

\section{nacjonalizmu}

DOI: http://dx.doi.org/10.12775/FT.2020.004

\begin{abstract}
(હ) $\oplus \Theta$
Tekst jest opublikowany na zasadach niewyłącznej licencji Creative Commons

Uznanie autorstwa-Bez utworów zależnych 4.0 Międzynarodowe (CC BY-ND 4.0).
\end{abstract}

łowa kluczowe: Karaimi; Polska; planowanie językowe; Seraja Szapszal; język turecki; Turcja

treszczenie: Już pod koniec XIX w. społeczności Karaimów dawnej Rzeczypospolitej zaczęły dyskutować w swojej prasie, jaki język wybrać, jako wspólny, czy też jak to zostało określone, język narodowy? Kwestia ta pozostała ważna w pierwszej połowie XX w. - uznano ją za narzędzie konsolidacji społecznej i kulturowej społeczności oraz ważny aspekt jej społecznego wizerunku w oczach polskiego społeczeństwa. Liderzy karaimscy próbowali kilku różnych strategii, począwszy od tradycyjnej dwujęzyczności (hebrajsko-tureckiej), po różne kombinacje rosyjsko-hebrajskiego, polsko-tureckiego itd. Inicjatywy te przybrały na sile na początku XX w., zwłaszcza po I wojnie światowej, kiedy etniczny nacjonalizm narodził się zarówno w środowisku karaimskim, jak i w dominującym społeczeństwie polskim. Analiza tych strategii językowych została przeprowadzona przy użyciu modelowego planowania językowego opracowanego przez Geoffreya Haiga w języku kurdyjskim we współczesnej Turcji, w ramach polityki Kemala Ataturka (Mustafa Kemal Atatürk, 1881-1938). W artykule zwrócono uwagę na te strategie, przeanalizowano argumentację oraz przedstawiono reformy językowe wdrożone w społeczności karaimskiej w pierwszej połowie XX w. Stwierdzono, że społeczny wizerunek Karaimów w dominującym społeczeństwie odgrywał ważną rolę w podejmowaniu decyzji przez karaimskich przywódców. Zrozumiano również, że język jest nie tylko ważnym aspektem karaimskiej tożsamości kulturowej, ale także narzędziem integracji z dominującym społeczeństwem. 


\section{Dovilè Troskovaitè}

Universität Vilnius. Fakultät für Geschichte

e-mail: dovile.troskovaite@gmail.com

ORCID ID: 0000-0001-7328-1913

Dr. Dovilè Troskovaitè ist wissenschaftliche Mitarbeiterin an der Fakultät für Geschichte der Universität Vilnius. Ihr Forschungsfeld umfasst vor allem (aber nicht ausschließlich) die Geschichte der osteuropäischen Karäer, ihre Beziehung zum rabbinischen Judentum sowie die Gesellschaft der Zeitspanne vom 18. zum 20. Jahrhundert. Sie ist Autorin der Abhandlung Kształtowanie się polskiej i litewskiej tożsamości karaimskiej w XIX-XX wieku: między separacją a adaptacją [Die Herausbildung der polnischen und litauischen Karäeridentität im 19.-20. Jahrhundert: zwischen Separation und Adaptation] (2014) sowie zahlreicher Beiträge und Tagungsvorträge zu diesem Thema. In den letzten Jahren beteiligte sie sich an einigen internationalen Projekten, die sich auf die Geschichte der Juden, die Identitätsgestaltung und ihre Änderung sowie auf die Erbschaft der nichtchristlichen Gesellschaften in Osteuropa bezogen.

\section{Die karaitischen Gemeinschaften: Nutzung der mehrsprachigen Sprachstrategien für den}

\section{Nationalismus}

DOI: http://dx.doi.org/10.12775/FT.2020.004

(c) $(\ominus$ Dieser Text wird unter der Creative Commons-Lizenz Namensnennung-Keine Bearbeitungen 4.0 International (CC BY-ND 4.0) veröffentlicht.

tichworte: Karäer; Polen; Sprachplanung; Seraja Szapszal; Türkisch; Türkei

usammenfassung: Schon am Ende des 19. Jahrhunderts begannen die Karäergemeinschaften der alten Republik Polen in ihrer Presse die Debatte darüber, welche Sprache als gemeinsam oder, wie man es bezeichnete, als Nationalsprache dienen sollte? Diese Frage war gültig noch in der ersten Hälfte des 20. Jahrhunderts. Man hielt sie für das Mittel zur sozialen und kulturellen Konsolidierung der Gemeinschaft sowie für einen wichtigen Aspekt ihres gesellschaftlichen Bildes in den Augen der polnischen Gesellschaft. Die Anführer der Karäergemeinschaft bedienten sich einiger Strategien, angefangen mit der traditionellen (hebräisch-türkischen) Zweisprachigkeit bis auf verschiedene Varianten von RussischHebräisch, Polnisch-Türkisch etc. Diese Initiativen nahmen am Anfang des 20. Jahrhunderts, vor allem nach dem Ersten Weltkrieg an Stärke, als der ethnische Nationalismus sowohl unter den Karäern als auch in der dominierenden polnischen Gesellschaft geboren wurde. Die Analyse dieser Sprachstrategien wurde mithilfe von der modellhaften Sprachplanung Geoffrey Haigs, bearbeitet in der kurdischen Sprache in der modernen Türkei im Rahmen der Politik Kemal Atatürks (Mustafa Kemal Atatürk, 1881-1938), durchgeführt. Im Beitrag wies man eben auf diese Strategien hin, analysierte die Argumentation und schilderte die 
Sprachreformen der Karäergemeinschaft aus der ersten Hälfte des 20. Jahrhunderts. Man stellte fest, dass in der dominierenden Gesellschaft das Bild der Karäer eine wichtige Rolle im Entscheidungsprozess ihrer Anführer spielte. Man konnte bemerken, dass die Sprache nicht nur ein wichtiger Aspekt der kulturellen Identität der Karäer, sondern auch ein Mittel zur Integration mit der dominierenden Gesellschaft ist. 